\title{
Metaphor in the Author's Comments
}

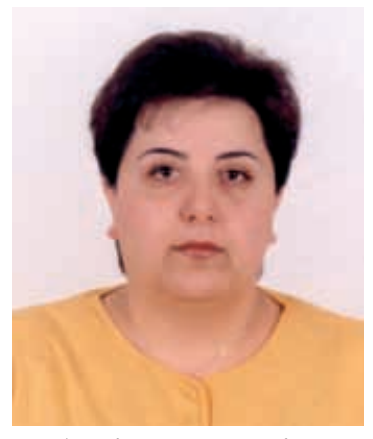

Armine Matevossian

T he ability to read, understand and appreciate a piece of literature is not an easy task at all, for literature is a "specific world" giving a good opportunity to study the diversity of imaginative elements, those inherent and adherent connotations which give birth to many new meanings.

It goes without saying that in the language of fiction there is a constant interplay of language units which offers a whole range of interpretations and makes an aesthetic impact on the reader. In this respect the creative use of stylistic devices in verbal art is worth mentioning, for tropes and figures of speech require careful study, inspiration and artistic effort.

Among all language units metaphor is one of the most powerful means, revealing the author's personal understanding of the surrounding world, his ideas and intentions. Metaphors figuratively suggest the author's goal, create artistic effects, and conjure up poetic images. Human language is profoundly metaphorical, and language as a whole has been figuratively defined as "a dictionary of faded metaphors". ${ }^{1}$

The present article touches upon the use of metaphor, its effect and realization in the author's comments in D.H. Lawrence's short stories. Lawrence's writings are beautiful and filled with sensual images. Each story seems to be simply a slice of life that describes the existence of simple people in simple circumstances, yet seen from extraordinary points of view. The beautiful use of language and imagery will attract the attention of almost every reader.

Lawrence's short stories offer brilliant flashes. He "can pack so much into such little space”(William York Tindalli,1961). Lawrence expresses his attitude towards the life of simple people in a succinct way, yet in every uttered word there is a hint of wisdom.

Lawrence was anxious to explore reality. "His great theme is the relationship: between man and man, woman and beast or anybody and the radiant universe"2. The stories prove and expand these connections. Man's great impulse, he said, is "to build a world, his own belief and to make through his own efforts something wonderful in this world” (William York Tindalli, 1961).

D. H. Lawrence is always "present" in his stories, as if he is following every action of his characters. Sometimes he interferes in the dialogues and gives his own reasons and motives, represents the heroes, their feelings, passions, beliefs, describes the subtle 
relationship of men and women. One cannot fail to observe that Lawrence creates the complex atmosphere by means of various stylistic devices and expressive means further emphasizing the relevance of metaphor.

An extract trom the story "New Eve and Old Adam" is a dialogue between a maried couple. The use of the author's comments is so natural and vivid that it is only with the help of them that the reader understands the atmosphere of the story, the passionate feelings of the female.

"Don' be horrid with me!" she pleaded, in a caressing, languid, soppy' voice. He shut his teeth hard, and his lips parted slighty with pain.

"You know you love me," she continued, in the same heavy, sing-song way. $H_{c}$ breathed hard but kept still.

"Don 't you?" she said. slowly, and she put her arms around his waist, under his coat, drawing him to her: It was as if flames of fire were running under his skin.

"I have never denied it," he said woodenly'

"You hate it that you have to love me". she said in a pensive voice through which the triumph flickered faintly:

"At anv rate, "he said, "it is your trimph."

She gave a sudden, bitter-contenptuous laugh.

(Lawrence D. H. "The Complete Short Stores". p. 73)

D. H. Lawrence is a master of creating a character. He describes the miserable state of the woman, the way she pleaded for her husband to be soft to her, to love her tenderly. And this becomes clear when the author uses the metaphorical expressions in his comments: she pleaded, in a caressing, languid, soppv voice, in the sane heany, singsong voice through which the tritmph flickered faintly, or she gave a bittercontemptuous laugh.

The above mentioned metaphorical expressions emphasize the gratifying desire of the female to be constantly loved. The adjectives (caressing, langwid, soppy, bittercontemptuots) convey the author's compassion lowards the female character. He introduces the realistic scene between the couple: despite being in triumph. the wife has a slight hesitation in her helpless voice.

Yet, as the author's comments prove, the man seems to be resentful and indifferent to her, (it was as ifflames of fire were ruming under his skin. or he said woodeniy).

Another story by D. H. Lawrence "The Prussian Officer" represents the life of a soldier. During his military service he has undergone serious difficulties and problems with his captain, who, having cut himself off from all people, has no passion or desire for the world around him.

The soldier, on the other hand, is a youth of about twenty-two, has a sweetheart, a girl from the mountains, independent and primitive.

The soldier feels the pressure and discontent of his officer and is almost aware that the captain experiences jealousy towards his own feelings. 
The youth stood before him, with his pathetic young motstache, and fine eyebrows very distinct on his forehead of dark marble.

"I asked you a question". The officer's fone bit like acid.

"Why had you a pencil in your ear?"

Again the servant's heart ran hot, and he could not breathe. With dark, strained eyes. he looked at the officer, as if fascinated. And he stood there sturdily planted, unconscious. The withering smile came into the Captain's eyes, and he lifted his foot. "I forgot it sir," panted the soldier, his dark eves fixed on the other man's dancing blue ones.

"What was it doing there?"

He saw the young man's breast heaving as he made an effort for ward.

Again the soldier looked him up and down. The officer could hear him panting. The smile cane into the blue eyes. The soldier worked his dry throat, but could not speak. Suddenly the smile lit like a flame on the officer's face, and a kick cane heavily against the orderly's thigh. The vouth moved sideways. His face went dead, with two black, staring eves.

"Well?" said the officer:

The orderly's mouth had gone dy, and his tongue rubbed in it as on dry brown paper: He worked his throat. The officer raised his foot. The servant went stiff.

"Some poetry, sir;" came the crackling, unrecognizable smile.

Again there was the w'orking in his throat. The Captain's heart had suddenly gone down heavily, and he stood sick and tired.

"For my girl, sir;" he heard the dry, inhuman sound.

"Oh!" he said, twming away: "Clear the table."

The young soldies w'as gone, looking old, and walking heavily.

The officer, left alone, held himself rigid, to prevent himself from thinking. Deep inside him was the intense gratification of his passion, still working powerfully.

Then there was a connteraction, a horrible breaking down of something inside him, a whole agony of reaction. He stood there for an hour motionless, a chas of sensations, but rigid with a will to keep blank his conscionsness, to prevent his mind grasping. And he held himself so mitil the worst of the stress had passed, when he began to drink, drank hinself to an intoxication, till he slept obliterated.

(The Prussian Officer p.103)

An experienced reader feels and acknowledges the richness of the vocabulary, the subtle nuances characterizing the heroes. It seems as if the author is aware of the characters' actions and behaviour, tries to penetrate into their inner world. I think all these are realizable, when the author is a master of the language, is full of imagination, and is able to express his thoughts through stylistic devices and expressive means.

The passage obviously shows that D. H. Lawrence sympathizes with the young soldier, though he is shown to readers as desperate. hopeless and excited. Metaphors and 
metaphorical expressions, as his pathetic young moustache; his forehead of dark monte: the servant's heart ran hot; he stood sturdily planted, unconscions; his face went dead; the crackling, unrecognizable sound of his voice; his dry. inhuman sound; are mostly used with negative adjeclives like pathetic, dark, unconscious, crackling, dry. inhuman and emphasize the fact that the young soldier is psychologically frustrated and agonized by his captain. The captain treats him bitterly with an acid tone. This is shown with the help of the author's comment in the following simile, the officer's tone bit like acid. The worst thing is that the captain's hatred and aversion for the youth has no limits. He becomes joyful learning that the servant is being tormented, his dark eyes fixed on the captsin's dancing blue ones; the snile came lit like a flame on the officer $s$ face; etc.

The picture becomes clearer and more vivid when we analyze the last part of the author's comments as well. Here, to show the character's desperate state, the author twice uses one of the most powerful devices, climax."

For example: Then there was a countcraction, a horrible breaking down of sonthing inside him, a whole agony of reaction.

And then the author passes to another example: ... he began to drink, drank himself to an intoxication, till he slept obliterated.

The captain, i. e. the hero of the passage, cannot hide his envy and he prefers to be drunk and be beyond self-control. The word intoxicuted, in which negative connotations come to the fore in the comtexi, goes with the whole stream of words, like, 10 be drunk, to be intoxicated, to be obliterated.

Presumably there could be other approaches to such an analysis, too, for literature gives boundless possibilities to think, to create, to analyse, to imagine, to interpret, to love and hate, to be for and against, to criticize and to evaluate.

Thus, we may conclude that the author's comments are one of the various stylistic means of creating literary personages and that the omnipresence of metaphor in the author's comments helps the reader to penetrate into the hidden essence of characters and to perceive fully the speech portrayed. Hence, metaphor; one of the most powerful devices, comes to be one of the effective means of fulfilling the author's aim, it is like an impeccable gem which creates a wealth of black and white tones and decodes the human nature in verbal art.

\section{References and Notes:}

1. In this connection Aristotle pointed out, "To find natural metaphors in the text means, to be able to notice the similarity of things and it is a great talent". Aristotle. "Antique Rhetorics". Moscow, MSU, 1978.

2. The most characteristic feature of Lawrence"s work is his contempt for reason and his reliance on the instincts. He understands love as natural, physical love that has nothing to do with intelligence, morality, or social rules. He thinks that 
there is something sacred in the basic instincts, against mind and prejudices. (See: Bemben Mathew, International Baccalaureatc English.)

3. It is a figure of speech based on such an arrangement of parts of an utterance whicl secures a gradual increase in semantic significance or emotional tension. Seе: Ахманова О. С. Словарь лингвистических терминов. М.,1966.

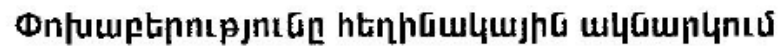

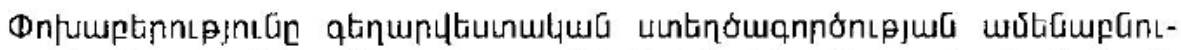

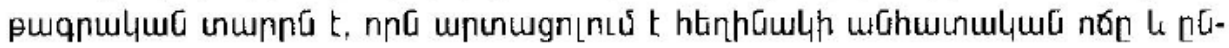

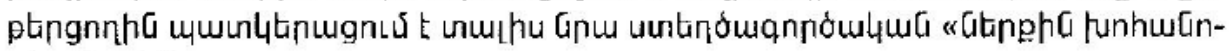
gh» טumuhG:

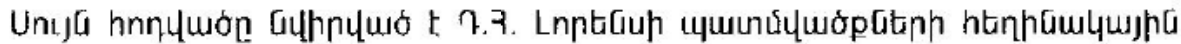

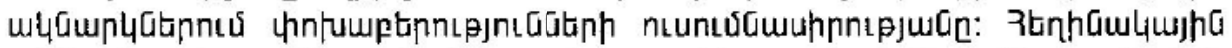

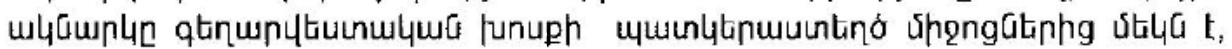

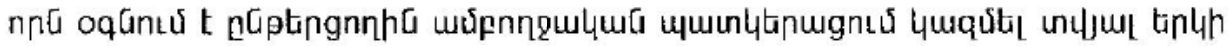

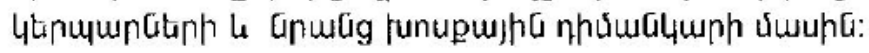

